DOI: 10.5824/1309-1581.2018.1.002.x

http://www.ajit-e.org/?menu=pages\&p=details_of_article\&id=303

Received : 15.01.2018 Editorial Process Begin: 02.02.2018 Published: 12.02.2018

\title{
Transmedya Hikayeciliği'nde Wattpad Örneği ve Okur Tercihlerine Yönelik Bir Araştırma
}

\author{
Kübra GÜRAN YiĞiTBAŞı, Marmara Üniversitesi, Yayıncılık Yönetimi, Yrd.Doç.Dr. \\ kubraguran@hotmail.com, https://orcid.org/0000-0002-2123-2973
}

$\ddot{\mathbf{O z}}$
Yeni medya dolayımıyla izleyici/kullanıcının, alımlama/okuma alışkanlıkları değişime uğramıştır. Yeni medyanın interaktif katılıma imkan tanımasıyla, alıcı medya içeriğini tüketen olmasının yanı sıra içeriği üreten, şekillendirebilen bir nitelik de kazanmıştır. Bu bağlamda alıcılar, anlatıya etki ederek içeriği dönüştürebilmektedir. Hedef kitlenin etkileş̧imini içeren bu anlatı tarzında, aynı içerik farklı platformlardan yayınlanarak daha geniş bir kitleye ulaştırllabilmektedir. Transmedya hikâye anlatıcılığ olarak adlandırılan bu kavrama göre, bir içerik çeşitlenerek birden fazla platformda alıcisına ulaşmaktadır.
Çalışmada, kullanıcılara ücretsiz olarak, hikayelerini paylaşma ve diğer üyelerin paylaşımlarını okuma platformu sağlayan bir uygulama olan "Wattpad” bir transmedya hikaye anlatıcılı̆̆ örneğ $i$ olarak ele alınmıştır. İlk olarak online bir hikaye okuma-yazma platformu şeklinde kullanıcısıyla buluşan Wattpad hikayeleri, basılı kitaplardan, sosyal ăglardaki hayran gruplarına ve sinema filmlerine kadar farkl mecralardan kitlesine ulaşmaktadır.
Çalışmada yapılan araştırmada Wattpad okur kitlesinin tercih ve alışkanlıklarının incelenmesi amaçlanmıştır. Söz konusu okur/hayran kitlesinin, Wattpad okuma tercihleri, Wattpad'den nasıl haberdar oldukları, arkadaşlarına tavsiye etme, yazar ve yayıncllarla iletişim kurma durumları ve en çok beğgendikleri kitap ve yazarlar araştırılmıştır.
Wattpad kullanıcılarının genel durumlarını incelemek için bu araştırmada nicel araştırma yöntemlerinden deneysel araştırma yöntemi uygulanmıştır. Veri toplama aracı olarak yüz yüze anket yapılmıştır. Çalışmanın hipotezlerinden ilki, Wattpad okuma tercihinde arkadaş ve sosyal çevrenin etkisinin bulunduğudur. Bir diğer hipotez, Wattpad yazarları ile kurulan iletişimin okuma alışkanlıklarını olumlu yönde etkilediğidir. Sonuncu hipotez ise, Wattpad okurlarının beğendikleri içerikleri, transmedya biçiminde farklı mecralarda da takip etmeyi tercih ettikleri yönündedir. Çalışmanın sonucunda tüm hipotezlerin doğrulandı̆̆ı görülmektedir.
Wattpad okurlarının çoğunluğunun, yazarlarıla iletişime geçmeyi tercih ettikleri, öncelikle mizahi ve sade bir dili olduğu için bu kitapları seçtikleri ve arkadaşlarının tavsiyesi ile okumaya başladıkları sonucuna ulaşılmıştır.

Anahtar Kelimeler: Wattpad, transmedya, okur, kullanıcl, yayıncllık.

\section{Wattpad As An Example Of Transmedia Storytellıng And An Examınation On Reader Prefences}

\footnotetext{
Abstract

The reception/reading habits of audience/users have changed as a result of the new media. Since the new media has enabled interactive participation, alongside being the consumers of the content, receivers are also able to produce and transform the content. In this context, receivers can transform content by acting in narrative. In this narrative style involving the interaction of the target group, same content can be published via various platforms, thus reaching a wider audience. According to this concept, which is called Transmedia storytelling, content can reach receivers on multiple platforms by diversifying.

In this study "Wattpad" was taken as an example of a transmedia storytelling, which is an application that allows users to share their stories and read other members' posts for free. Wattpad stories which
} 


\begin{abstract}
initially met their readers on an online story-telling platform, has now reached mass media, ranging from printed books, social networking fan groups and motion pictures.

This study aims to investigate the preferences and habits of Wattpad readers in the study. Our research examines readers/audiences reading preferences, how they learned about Wattpad, if they would recommend Wattpad to friends, whether or not they communicate with writers and publishers, and their favourite books and authors.

To investigate the general situation of Wattpad users, experimental research method which is one of the quantitative research methods was applied in this research. A face-to-face survey was conducted as a data collection tool. First of the few hypotheses of the study is that friends and social circles play role in the preference of reading Wattpad. Another hypothesis was that communicationwith Wattpad authors positively affect reading habits. The last hypothesis, claim that Wattpad readers prefer to follow the content they like in transmedia-style through other social media tools. As the result of the study all the hypotheses are proven.

The conclusions of the study show that; the majority of Wattpad readers prefer to communicate with their writers, readers have chosen and read such content primarily because they are humorous and have simple language, and users have usually reached these through their friends' recommendations.
\end{abstract}

Keywords: Wattpad, transmedia, reader, user, publishing

\title{
Giriş
}

Yeni medya araç ve mecraları gündelik hayat alışkanlıklarımızda pek çok değişimi beraberinde getirmiştir. Yaşam pratiklerimizde tüketim, eğitim, arkadaşlık ve sosyal ilişkilerde bu değişim açıkça görülmektedir. Bunun yanı sıra, özellikle gençlerin okuma ve yazma alışkanlıklarını değiştiren ve dönüştüren platform ve mecralar gün geçtikçe daha çok kullanıcıya ulaşmaktadır. Wattpad, bu duruma önemli bir örnek olarak karşımıza çıkmaktadır.

2006 yılında Toronto' da kurulan bir şirket olan Wattpad, çoğunlukla akıllı telefonlardan, yanı sıra bilgisayar ve tabletlerden de takip edilebilen bir hikaye yazma, paylaşma ve okuma platformudur. Kuruluşundan bu yana kırk milyon üyeye, farklı ülkelerden milyonlarca yazara sahip olan Wattpad'in bazı içerikleri, yüz milyondan fazla okunma sayısına ulaşmıştır. Buradan hareketle, kullanıcıların wattpadde geçirdiği süre, yaklaşık her ay on bir milyar dakika olarak hesap edilmektedir (Karauğuz, s.608).

Wattpad, bedava e-kitap bağlantısı sağlayan ve android aplikasyonu olan bir uygulama olduğundan, hikaye ve roman yazarlarının eserlerini yayımlaması için bir fırsat sağlamaktadır. Bu elektronik yazma ve okuma uygulaması sayesinde, özellikle genç ve beğenilen yazarların hikayelerinin çeşitli yayınevleri tarafından yayınlanmasına da olanak sağlanmaktadır (Aytan, s.2).

Wattpad'de kullanıcıların yüzde 10'nu aynı zamanda içerik yazan okuyucular oluştururken, kullanıcıların yüzde 90'1 ise yorumlayan, paylaşan, oylamalara katılan okuyuculardır (Bold, s.5).

Transmedya hikaye anlatıcılığı kapsamında çalışmada, kullanıcı/okuyucuların online bir platform kanalıyla ulaştıkları bir anlatı olan wattpad hikayelerini tercih sebepleri araştırılmıştır.

Kullanıcıların beklentilerini ve tercih nedenlerini anlamak, yeni yayıncılık platformlarının okur, yazar ve yayıncı için anlamını da ortaya çıkaracaktır. 


\section{Transmedya hikaye anlatıcılığı}

Transmedya hikâye anlatıcılığı, sinemada gösteriminden bir yıl kadar önce, internetten hayranlarını yaratmış olan "Blair Cadısı" filmi ile 1999'da gündeme gelmiştir. Film gösterime girmeden önce, ana konusu olan yapım ekibinin ortadan kayboluşunun ayrıntılarını internetteki ilgili siteden paylaşılmıştır. Filmin gösterime girmesinin ardından, cadılarla ilgili çeşitli çizgi romanlar piyasaya sürülmüş, filmin müziği ise terk edilmiş bir arabada bulunan bir kaset ile izleyenlere ulaşmıştır. (Jenkins, 2016, s.152) Buradan hareketle transmedya hikaye anlatıcılığı, izlerkitlenin içeriği farklı medya platformları arasında takip etmeyi talep etmesi üzerine kurgulanan yeni bir dünya olarak düşünülebilir. Burada önemle üzerinde durulması gereken noktalardan birisi, farklı mecralarda aynı içeriğin çeşitli şekillerde sunumu, diğeri ise bir hayran kitlesinin bu çeşitli mecralarda sunulan içerikleri pasif bir şekilde tüketmekle kalmayarak, üretime de katkı sağlama çabasındaki bir topluluk oluşturmasıdır. Bu bağlamda, transmedya hikaye anlatıcılığında hayran topluluklarının önemini yadsımamak gerekmektedir.

Örneğin hayran topluluklarının, çeşitli medya mecralarında sunulan anlatılardan yola çıkarak, bilgi açıklarını ve merak duygularını tatmin edebilmek için izler sürmesi, tartışma grupları aracılığıla da kendi yorumlarını birbirleriyle paylaşmaları, kavrayış ve deneyimlerini canlı tutacaktır (Jenkins, 2016, s. 143-145) Storey (s.157) altkültür gençliğinin kendilerini egemen kültür ve ebeveyn karşıt1 olarak; hayran topluluklarının ise gündelik hayatın sıradanlığının ve kültürel pasifliğinin karşıtı şeklinde konumlandırdıklarını belirtmektedir. Transmedya örneği olarak çalışmada ele aldığımız Wattpad hikayelerinde de egemen kültür ve ebeveyn karşıtlığı oldukça sık yer almaktadır.

Hayati $(2012,199)$ bir transmedya üretiminin, farklı medya mecraları arasında hikâyeler geliștirmenin yanı sıra, aynı zamanda mecraların birbiriyle anlatı senkronizasyonu içinde de bulunduğunu belirtmektedir. (Aktaran Sarı, s.246). Çeșitli medya platformlarında yeni metinlerle ortaya çıkan transmedya hikâyeciliğnde, bir hikâye bir filmde tanıtılır, televizyon, roman ve çizgi romanlarla geniş̧etilir; dünyası oyun oynayarak kesf̧edilebilir veya eglence parkı cazibesi olarak deneyimlenebilir. Ancak her bir içeriğin tek başına da anlam yaratabilmesi için kendi içinde bağımsız olması gerekir (Jenkins, 2016, s.144-145). Eğlenceyle pazarlamayı birleştiren bu yeni anlatı yaklaşımının arkasında önemli ekonomik gerekçeler bulunmaktadır. Bu bağlamda, transmedya hikayeciliğinin, tüketici ya da hayran/okur/izler kitlenin aynı zamanda üretici olmasını da beraberinde getirdiği düşünülebilmektedir. Bunun yanı sıra izlerkitlenin üretime katkısı olabilmesine karşın, ticari bir kazancı bulunmamaktadır. Üreticiler tüketicileri memnun etmeyi, tüketiciler ise üreticileri memnun etmeyi amaçlamakta böylece, üretici-tüketici arasındaki ayrımın ortadan kalkmasıyla herkesin kullanıcı haline geldiği öne sürülmektedir (Laughey, 2010, s.67).

Sonuç olarak, transmedya hikaye anlatıcılığının genel olarak var olma ve tercih nedenleri Sezen (2014, s.42-44) tarafından şöyle belirtilmiştir:

-Var olan ürün çeşitliliği arasında tüketiciyi markaya çekme süreci zorlaşmıştır. Bu nedenle geleneksel içerik endüstrileri kullanıcıları eğlendirerek, ilgilerini çekebilecek yaratıcı ve yenilikçi yöntemler bulma ihtiyacındadır.

-Dijital yerli olarak adlandırılan kuşağın, medya ile kurduğu iletişim biçiminin, içeriği hem üreten hem de tüketen olarak farklı bir boyuta ulaştırmıştır. 
-Katılımcı olan ve edilgen olmayan izleyici kavramının yer etmesiyle, televizyon izlerken aynı zamanda izlediği ile bağlantılı olarak sosyal medyayı da kullanan bir kitle oluşmutur.

-Birden fazla yani çoklu etkinlik içinde olma talebindeki kitle için, aynı zamanda birden fazla medyayı eş zamanlı, aktif kullanabilecekleri uygun içeriklerin hazırlanabilmesi beklentisi bulunmaktadir.

-Sosyal medya ve mobil teknolojiler, büyük grupların oluşması, bir arada hareket edebilmesine imkan tanımış ve bu durum kolekif zeka kavramını oluşturmuştur.

-Her mecra ve platformda erişilebilen oyunlar anlatının bir parçası haline gelmiştir.

-İçerikler platformlar arasında hareketli hale gelmiş ve platformlar arasında sınırlar belirsizleşmiştir.

\section{Araştırmanın amacı}

Literatürde ülkemizde Wattpad okurlarına yönelik yapılan herhangi bir nicel araştırmaya rastlanamadığından, böyle bir nicel durum analizi yapılmasına ihtiyaç duyulmuştur.

Araştırmada, Wattpad okur/kullanıcı kitlesinin Wattpad hikayeleri ile ne şekilde tanıştıkları, okur beklentileri ve Wattpad hikayelerini tercih sebeplerinin ortaya konması amaçlanmıştır. Bu bağlamda Wattpad hikayeleri ile tanışma ve okuma tercihinde arkadaş ve sosyal çevrenin etkisinin bulunduğu, Wattpad yazarları ile kurulan iletişimin okuma alışkanlıklarını olumlu yönde etkilediği ve Wattpad içeriklerinin, transmedya olarak farklı mecralarda yer almasının tercih edildiği hipotezleri araştırılmıştır.

Bu amaçla, Wattpad'in Türkiye'deki tüm okur kitlesine ulaşmak mümkün olmadiğından, doğrudan Wattpad okuruyla yüz yüze anket yapılabilmesi için Tüyap fuarı süresince Wattpad kitapları yayınlayan çeşitli yayınevlerinin standlarında bulunan ya da imza günlerine katılan Wattpad okurları ile görüşülmüştür. Araştırmaya 332 kişi katılmıştır.

Çalışmada, sözü edilen hipotezlere ek olarak “Türkiye'de Wattpad okurlarının Wattpad hikayelerini beğeni sebepleri nelerdir?", "Wattpad okurlarının Wattpad hikayelerini tercih nedenleri nelerdir?" gibi sorulara da cevap aranmaktadır.

\section{Araştırma yöntemi}

Wattpad kullanıcılarının genel kullanım alışkanlık ve terchihlerini incelemek için bu araştırmada nicel araştırma yöntemlerinden deneysel araştırma yöntemi uygulanmıştır. Veri toplama aracı olarak yüz yüze anket yapılmıştır. Araştırmanın çözümlemesinde betimsel (freknas analizi, çapraz tablolama, grafikleme) ve çıkarımsal (korelasyon analizi, farklılık testleri) istatistiksel yöntemlerden yararlanılarak toplanan veriler bilgisayar ortamında "IBM SPSS Statistics 24" istatistik paket programında analiz edilmiştir. 


\section{Araştırmanın kapsam ve sınırlılıkları}

Araştırma kapsamında; 04 - 12 Kasım 2017 tarihleri arasında Tüyap Fuar ve Kongre Merkezi, Büyükçekmece/İstanbul' da gerçekleştirilen 36. Uluslararası İstanbul Kitap Fuarı'nı ziyaret eden, imza günlerine katılan Wattpad okurları ile yüz yüze anket yapılmıştır.

Bu bağlamda, araştırma, 4-12 Kasım 2017 tarihlerinde ilgili fuarı ziyaret eden Wattpad okurlarıyla sınırlıdır. Araştırma kapsamında araştırma evreninin tamamına yani Türkiye'deki tüm Wattpad kullanıcılarına ulaşmak mümkün olmadığından, kapsam hali hazırda Tüyap kitap fuarına katılan okur kitlesiyle sınırlıdır. Bu bağlamda daha önce Wattpad okur/kullanıcısı hakkında Türkçe olarak yapılan bir araştırmaya rastlanamadığından, araştırmanın konuyla ilgili yapılacak gelecekteki diğer çalışmalar açısından bir temel oluşturacağı düşünülmektedir.

\section{Araştırmanın önemi}

Transmedya hikaye anlatıcılığı ekseninde ele aldığımız Wattpad hakkında yapılan Türkçe çalışmalar sayıca yetersizdir. Az sayıda bulunan Türkçe çalışmada ise Wattpad hikaye/içerikleri üzerine yoğunlaşılmıştır.

"Transmedya hikaye anlatıcılı̆̆ı: Kötü Çocuk Örneği” adlı makalesinde Sarı (2017) "Kötü Çocuk” adlı wattpad hikayesinin basılı kitap, sosyal medya ve sinema filmi gibi mecralarda kendini gösteren bir transmedya örneği olduğunu belirtmiştir. Buna göre, hikaye Wattpad'de yayınlanıp yaklass,k olarak 142 milyon kez okunmus, sonrasında 350 bin adet basılıp dört bölüm halindeki basılı bir kitap olarak yayınlanmıştır. Öte yandan kitabın kapak fotografı poster ve CD, ayraç olarak da sunulmustur. Sosyal medyada ise@kotucocukserisi@kotucocukfilm@busra.kck kullanicı adlarıyla twitter ve instagram gibi mecralarla, hikaye anlatısının devamı sağlanmış; son olarak da anlatı, 20 Ocak 2017'de vizyona giren bir sinema filmine dönüşmüștür (s.250)

Wattpad içeriklerinin karakteristik özelliklerine değinen Karauğuz (2016) ise çalışmasında, yazım aşamasında imla ve dilbilgisi gibi herhangi bir kurala bağlı olmayan Wattpad hikayelerinin, ele aldıkları konuların da genellikle uçlarda yaşayan, ütopik konular olduğunu belirtmektedir. $\mathrm{Bu}$ bağlamda çalışmasında, Wattpad ile popüler olan genç yazarların oluşturduğu bu içeriklerin, edebiyata zarar veren bir yanı olup olmadığı tartışmalarına yer vermiştir. (s.609-610)

Wattpad'i e-kitap okuma kültürü ekseninde değerlendirerek Yabancı adlı Wattpad hikayesini inceleyen Çoban (2015) araştırmasında, kızların erkeklere oranla, kendi yaşıtları tarafından yazılan e-kitapları tercih ettiğine işaret etmiştir. Çoban, Yabancı adlı kitaba okurlarından gelen destek ve yorumlardan hareketle, Wattpad hikayelerinin okurları olan genç kızlar üzerinde, konunun sunuluş şekli ve okurların duygularını harekete geçirme gücü açısından önemli etkisi olduğunu belirtmiştir. (s.596-597)

\section{Araştırma}

Ankete katılan Wattpad kullanıcılarının \%88'ini (292 kişi) kızlar, \%12'sini (40 kişi) ise erkekler oluşturmaktadır. Buna göre, Wattpad hikayelerinin yazarları genellikle genç kızlardan oluştuğu gibi, okurları da araştırmaya göre çok büyük çoğunlukla kızlardan oluşmaktadır. 

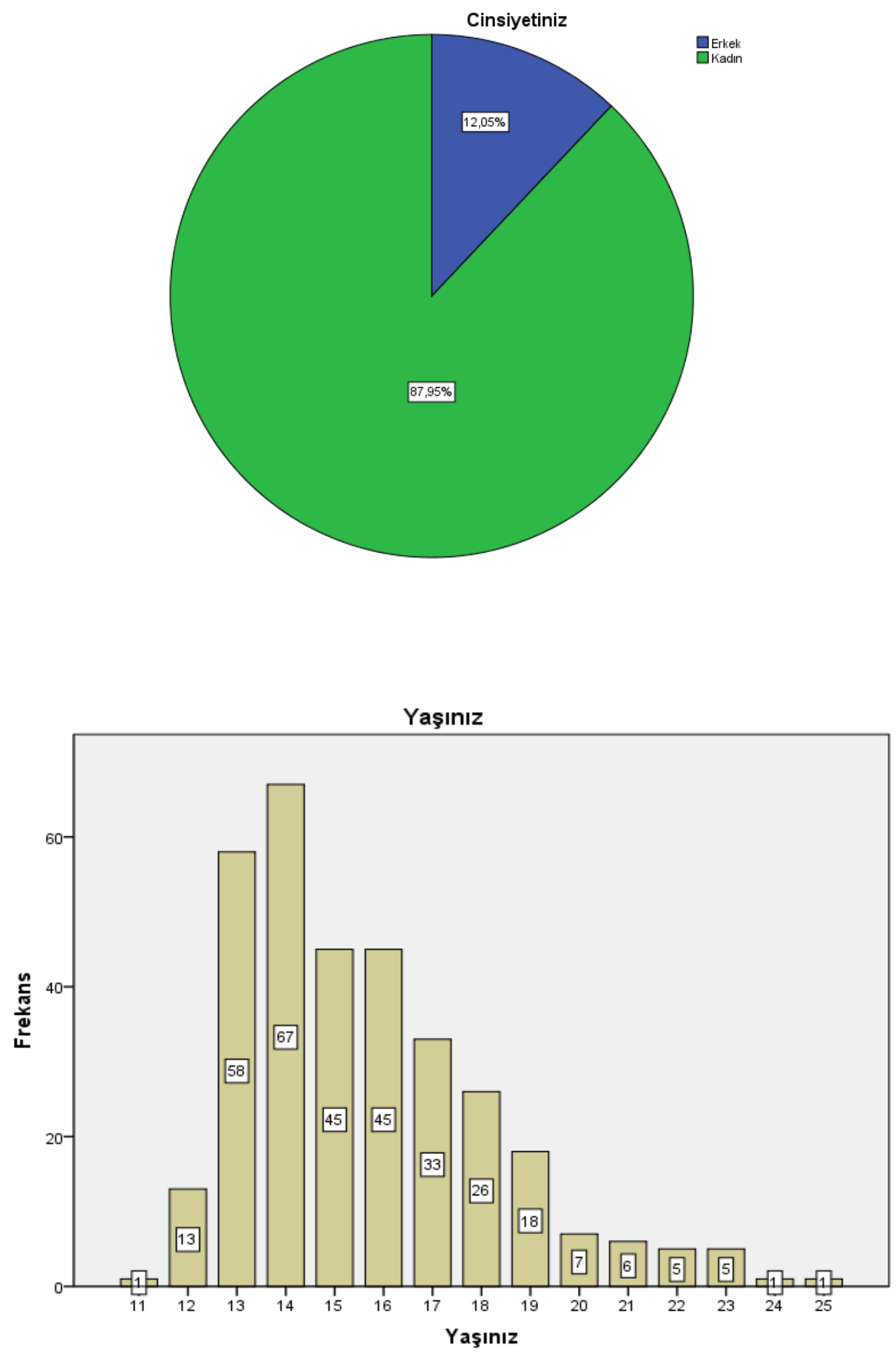

http://www.ajit-e.org/?menu=pages\&p=details_of_article\&id=303 
Ankete katılan Wattpad kullanıcılarının büyük çoğunluğu 13-17 yaş grubundadır. Grubun yaş ortalaması 15,6 olup, ankete katılanların en alt yaş sınırı 11, en üst yaş sınırı da $25^{\prime}$ dir. Araştırma için yapılan ankete en fazla sayıda kişi (67 kişi) ile 14 yaşındakiler katılım göstermiştir. $\mathrm{Bu}$ sonuçlardan hareketle, Wattpad içerik/hikayelerinin büyük oranda lise düzeyindeki gençlere hitap ettiği görülmektedir.

\begin{tabular}{|c|c|c|c|c|c|}
\hline \multicolumn{6}{|c|}{ Eğitim Seviyeniz * Eğitim Gördüğünüz Okul Türü } \\
\hline & & & \multicolumn{2}{|c|}{ Ĕgitim Gördüğünüz Okul Türü } & \multirow[b]{2}{*}{ Toplam } \\
\hline & & & Özel & Devlet & \\
\hline \multirow{4}{*}{$\begin{array}{c}\text { Eğitim } \\
\text { Seviyeniz }\end{array}$} & \multirow{2}{*}{ Ortaokul } & Say1 & 26 & 90 & 116 \\
\hline & & \% Eğitim seviyeniz & $22,4 \%$ & $77,6 \%$ & $100,0 \%$ \\
\hline & Lise & $\begin{array}{l}\text { Sayı } \\
\% \text { Eğitim seviyeniz }\end{array}$ & $\begin{array}{c}24 \\
15,4 \% \\
\end{array}$ & $\begin{array}{c}132 \\
84,6 \% \\
\end{array}$ & $\begin{array}{c}156 \\
100,0 \% \\
\end{array}$ \\
\hline & Lisans & $\begin{array}{l}\text { Sayı } \\
\% \text { Eğitim seviyeniz }\end{array}$ & $\begin{array}{c}21 \\
37,5 \% \\
\end{array}$ & $\begin{array}{c}35 \\
62,5 \% \\
\end{array}$ & $\begin{array}{c}56 \\
100,0 \% \\
\end{array}$ \\
\hline \multirow[t]{2}{*}{ Toplam } & & Say1 & 71 & 257 & 328 \\
\hline & & $\%$ Toplam & $21,6 \%$ & $78,4 \%$ & $100,0 \%$ \\
\hline
\end{tabular}

Tablo 1. Eğitim Seviyeniz * Eğitim Gördüğünüz Okul Türü

Ankete katılan Wattpad kullanıcılarının eğitim seviyeleri ve eğitim kurumları incelendiğinde, ortaokul öğrencilerinin 26's1 $(\% 22,4)$ özel ve 90'1 $(77,6)$ devlet okulu olmak üzere toplam 116 kişi, lise öğrencilerinin 24'ü $(\% 15,4)$ özel, 132'si $(\% 84,6)$ devlet olmak üzere toplam 156 kişi ve üniversite öğrencilerinin 21 'i vakıf $(\% 37,5)$, 52'si $(\% 62,5)$ devlet olmak üzere toplam 56 kişidir. Görüldügü gibi ankete katılan wattpad kullanıcılarının yaklaşık olarak \%80’i devlet okulunda okumaktadir.

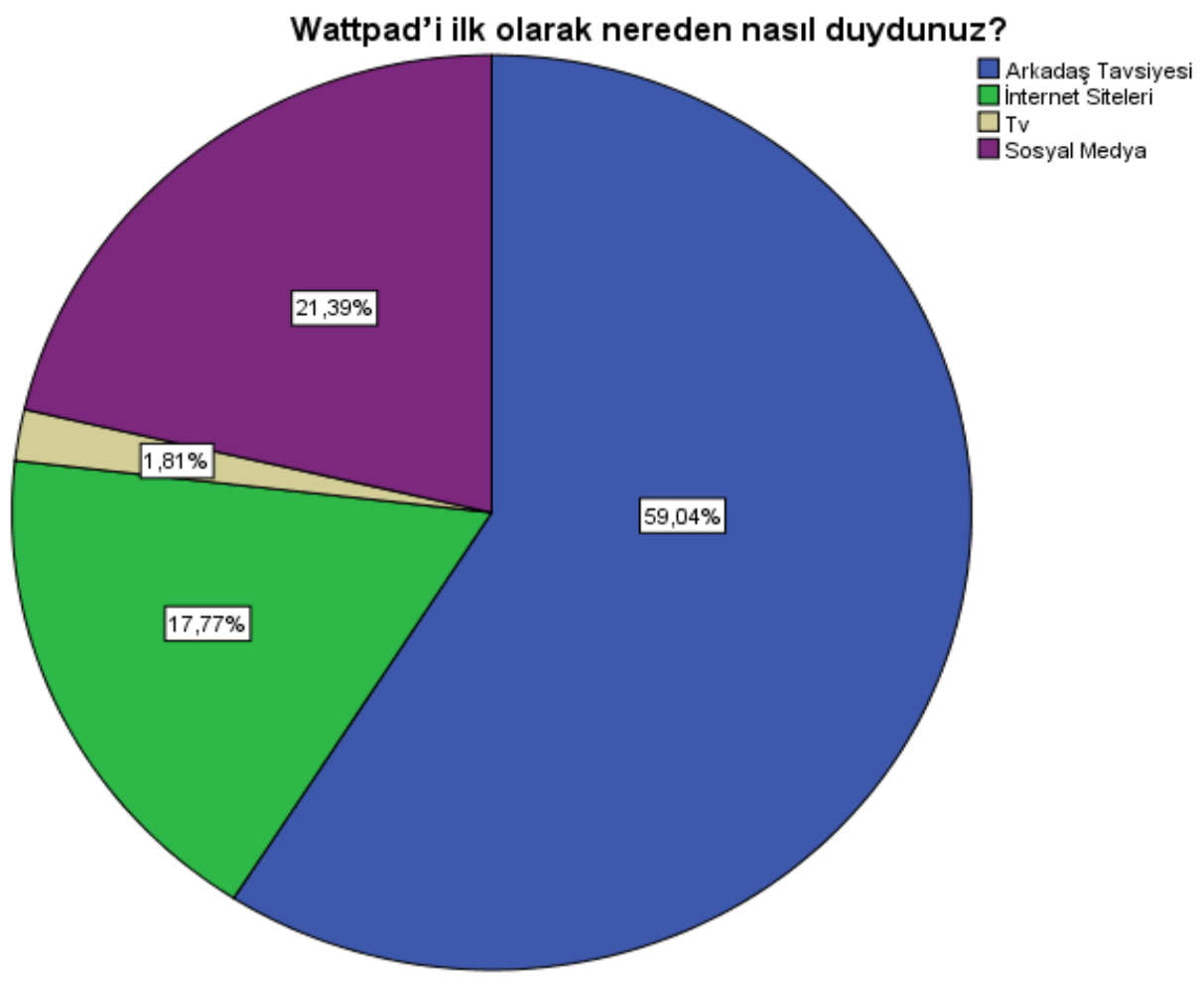


Şekil 1. Kullanıcıların Wattpad'i Nereden Duyduklarına İlişkin Şema.

Ankete katılan Wattpad kullanıcılarının \%60’1 Wattpad uygulamasını arkadaşlarından, geri kalanların yarısı wattpad'i sosyal medyadan, neredeyse kalanların tamamı da internet sitelerinden duymuşlardır. Buradan yola çıkarak, araştırmaya katılan Wattpad okurlarının yarısından fazlasının arkadaşları sayesinde haberdar olduğu ve Wattpad okumaya başladıkları anlaşılmaktadır. Geriye kalan okurların yarısı sosyal medya yoluyla, diğer yarısı da internet siteleri aracılığıyla Wattpad okumaya başlamışlardır. Wattpad'in yayılımında sosyal çevrenin yani arkadaş çevresi ve sosyal medya uygulamalarının etkisi diğer mecralara nazaran çok öndedir.

Ankete katılanların \%36'sının (117 kişi) Wattpad fun club üyeliği bulunurken, \%64'ünün (197 Kişi) henüz üyelikleri bulunmamaktadır. Fun club üyeliği durumu ile katılımcıların wattpadden takip edip hoşlandıkları yazarlar ya da yayıncılarla sosyal medyadan iletişime geçme durumları çapraz tabloda incelenmiştir.

Fun club üyeliğiniz var mı * Wattpad'den takip edip hoşlandığınız yazarlar ya da yayıncılarla sosyal medyadan iletişime geçiyor musunuz? Çapraz Tablolama

\begin{tabular}{|c|c|c|c|c|c|}
\hline & & & \multicolumn{2}{|c|}{$\begin{array}{l}\text { Wattpad'den takip edip hoşlandığınız } \\
\text { yazarlar ya da yayıncılarla sosyal } \\
\text { medyadan iletişime geçiyor musunuz? }\end{array}$} & \multirow[t]{2}{*}{ Toplam } \\
\hline & & & Evet & Hayır & \\
\hline \multirow{2}{*}{$\begin{array}{l}\text { Fun club } \\
\text { üyeliğiniz var mı? }\end{array}$} & Evet & $\begin{array}{l}\text { Sayı } \\
\text { \%Yüzde }\end{array}$ & $\begin{array}{c}42 \\
77,8 \% \\
\end{array}$ & $\begin{array}{c}12 \\
22,2 \% \\
\end{array}$ & $\begin{array}{c}54 \\
100,0 \% \\
\end{array}$ \\
\hline & Hayır & $\begin{array}{l}\text { Sayı } \\
\text { \%Yüzde }\end{array}$ & $\begin{array}{c}75 \\
28,8 \% \\
\end{array}$ & $\begin{array}{c}185 \\
71,2 \%\end{array}$ & $\begin{array}{c}260 \\
100,0 \%\end{array}$ \\
\hline Toplam & & $\begin{array}{l}\text { Sayı } \\
\text { \%Yüzde }\end{array}$ & $\begin{array}{c}117 \\
37,3 \% \\
\end{array}$ & $\begin{array}{c}197 \\
62,7 \%\end{array}$ & $\begin{array}{c}314 \\
100,0 \%\end{array}$ \\
\hline
\end{tabular}

Tablo 2. Fun Club Üyeliği *Sosyal Medyadan İletişime Geçme Durumu

Buradan hareketle ulaşılan sonuçlardan birisi, çoğunluğun fun club üyeliği olmaması ancak bir diğer sonuca göre ise fun club üyeliği olanların çoğunun yazar ya da yayınevi ile iletişim kuruyor oluşudur. Fun club üyeliği olanların \%77,8'i hoşlandıkları yazar ya da yayınevi ile sosyal medya üzerinden iletişim kurmaktadırlar. Öte yandan dikkat çeken bir durum ise herhangi bir fun club üyeliği olmadığı halde sosyal medya üzerinden beğendiği yazar ve yayıncılarla iletişime geçenlerin oran 1 ise $\% 28,8$ 'dir.

\section{Haftada ne kadar Wattpad okursunuz?}

\begin{tabular}{|c|c|c|c|}
\hline & Frekans & Yüzde (\%) & Kümülatif Yüzde \\
\hline 0-30 & 68 & 20,5 & 20,5 \\
\hline 30-1 saat & 87 & 26,2 & 46,7 \\
\hline 1-2 saat & 90 & 27,1 & 73,8 \\
\hline 2-3 saat & 26 & 7,8 & 81,6 \\
\hline 3-5 saat & 17 & 5,1 & 86,7 \\
\hline 5-7 saat & 10 & 3,0 & 89,8 \\
\hline
\end{tabular}




\begin{tabular}{ll|lll}
\hline 7-10 saat & 10 & 3,0 & 92,8 \\
\hline 10 saatten fazla & 24 & 7,2 & 100,0 \\
\hline Toplam & 332 & & 100,0 & \\
\hline
\end{tabular}

Tablo 3. Haftalık Wattpad Okuma Süresi

Ankete katılanların \%74'ü haftada 2 saat ve daha az Wattpad okuduklarını belirtmişlerdir. Haftada 10 saatten fazla Wattpad okuyanların sayısı azımsanmayacak seviyede olup, oranı ise \%7'nin üzerindedir.

Ankete katılan Wattpad kullanıcılarının çok büyük çoğunluğu \%92'si akıllı telefondan, \%4,5'i tablet e-okuyucadan ve \%3,3'ü ise basılı kitaplardan Wattpad'i takip etmektedirler. Akıllı telefonların Wattpad uygulamasına ulaşım noktasındaki kolaylığı ve sürekli el altında olmasının etkisi soruların cevaplarında açıkça görülmektedir.

\begin{tabular}{|c|l|r|r|}
\hline \multicolumn{2}{|c|}{$\begin{array}{c}\text { Wattpad'i nereden takip } \\
\text { ediyorsunuz? }\end{array}$} & Frekans & Yüzde (\%) \\
\hline \multirow{3}{*}{$\begin{array}{c}\text { Takip } \\
\text { Yöntemi }\end{array}$} & Ak1llı Telefon & 306 & $92,2 \%$ \\
\cline { 2 - 4 } & Tablet-e okuyucu & 15 & $4,5 \%$ \\
\cline { 2 - 4 } & Basılı Kitap & 11 & $3,3 \%$ \\
\cline { 2 - 4 } & Toplam & 332 & $100,0 \%$ \\
\hline
\end{tabular}

Tablo 4. Wattpad Takip Mecrası

Ankete katılan okurların wattpad hikayelerini tercih etme nedenlerini belirlemeye yönelik, "Wattpad hikayelerini tercih etmenizin en önemli nedenleri nelerdir?" sorusu yöneltilmiştir. Katılımcıların en önemli 3 nedeni işaretlemeleri istenmiştir. Verilen cevapların oranları aşağıda belirtilmiştir.

Wattpad hikayelerini tercih etmenizin en önemli nedenleri nelerdir? (En önemli ilk üç seçeneği işaretleyiniz)

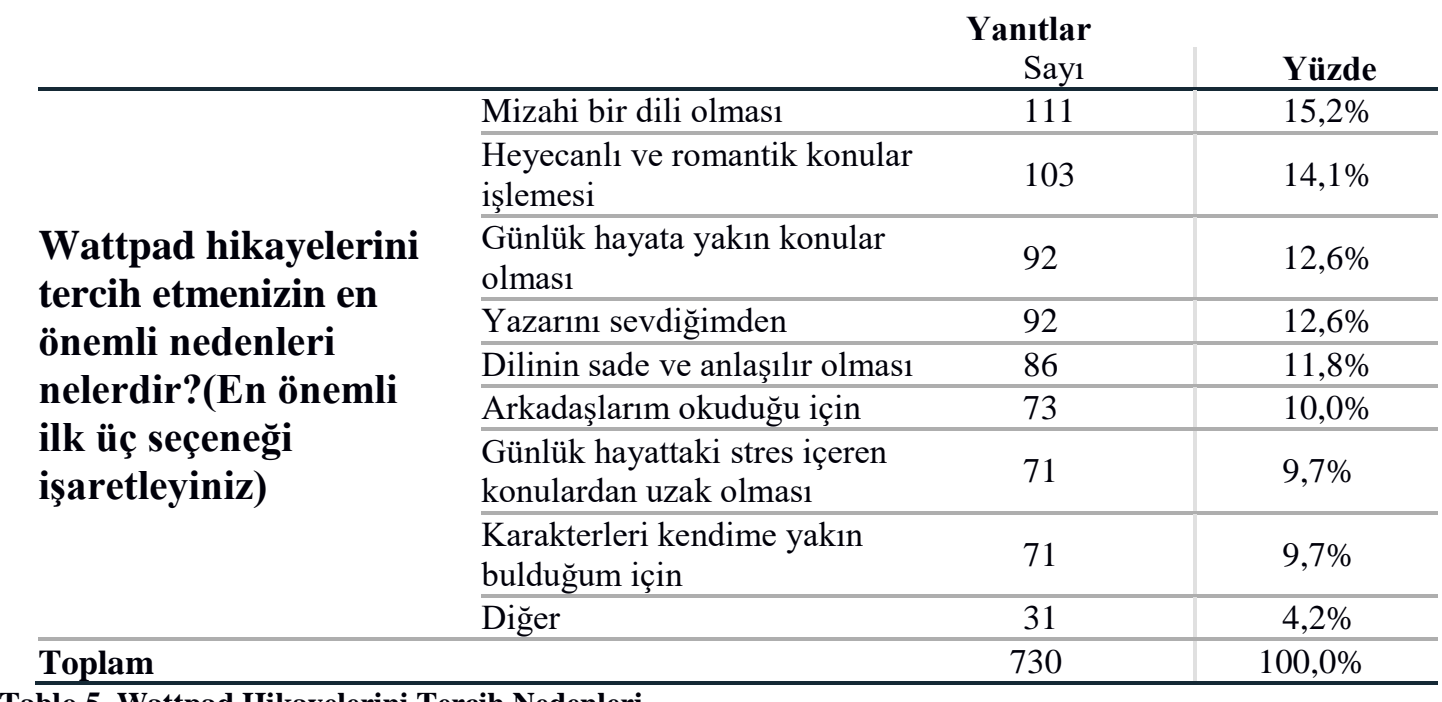

Tablo 5. Wattpad Hikayelerini Tercih Nedenleri

Wattpad hikayelerinin tercih nedenlerine genel olarak bakıldığında, hepsinin yüzdelerinin birbirine yakın olduğu gözlenmiştir. Hikayelerin en fazla tercih edilme nedenine verilen cevapların ilk üçünde; 
- \%15,2 'si 111 kişi "mizahi bir dili olması"

- \%14,1'i 103 kişi "Heyecanlı ve romantik konular işlemesi"

- \%12,6'sı 92 kişi "Yazarını sevdiğimden" ve "Günlük hayata yakın konular olması" bulunmaktadir.

En az tercih edilen nedenler ise \%9,7 ile "karakteri kendime yakın bulduğum için" olmuştur. Diğer cevabını işaretleyenlerin oranı ise $\% 4,2$ 'dir.

Ankete katılan wattpad okuyucularının beğendikleri yazarlarla iletişime geçme oranı düşük olmasına rağmen, Wattpad tercih nedenlerinde "yazarını sevdiğimden" ifadesinin oranı yüksektir. Görüldüğü gibi Wattpad içerikleri yazarın kendisine duyulan sempatiden ötürü de tercih edilebilmektedir. Bu durumu daha detaylı aşağıdaki Tablo 6'da belirtilmiştir.

\section{Tercih Nedeni-İletişime Geçme- Çapraz Tablolama}

\begin{tabular}{|c|c|c|c|c|c|c|c|c|c|c|}
\hline & & $\begin{array}{l}\text { Dilinin sade } \\
\text { ve anlaş1lır } \\
\text { olması }\end{array}$ & $\begin{array}{l}\text { Günlük } \\
\text { hayata } \\
\text { yakın } \\
\text { konular } \\
\text { olması }\end{array}$ & $\begin{array}{l}\text { Heyeca } \\
\text { nlı ve } \\
\text { romanti } \\
\mathrm{k} \\
\text { konular } \\
\text { işlemesi }\end{array}$ & $\begin{array}{l}\text { Mizahi } \\
\text { bir dili } \\
\text { olmas1 }\end{array}$ & $\begin{array}{l}\text { Günlük } \\
\text { hayattaki } \\
\text { stres } \\
\text { içeren } \\
\text { konularda } \\
\text { n uzak } \\
\text { olması }\end{array}$ & $\begin{array}{l}\text { Yazarın } \\
1 \\
\text { sevdiği } \\
\text { mden }\end{array}$ & $\begin{array}{l}\text { Karakterler } \\
\text { i kendime } \\
\text { yakın } \\
\text { bulduğum } \\
\text { için }\end{array}$ & $\begin{array}{l}\text { Arkadaşla } \\
\text { rım } \\
\text { okuduğu } \\
\text { için }\end{array}$ & Diğer \\
\hline $\begin{array}{l}\text { Wattpad'de } \\
\text { n takip edip }\end{array}$ & Evet & $36,0 \%$ & $32,6 \%$ & $40,8 \%$ & $28,8 \%$ & $40,8 \%$ & $51,1 \%$ & $50,7 \%$ & $24,7 \%$ & \\
\hline musunuz? & Hayır & $64,0 \%$ & $67,4 \%$ & $59,2 \%$ & $71,2 \%$ & $59,2 \%$ & $48,9 \%$ & $49,3 \%$ & $75,3 \%$ & $1,6 \%$ \\
\hline Toplam & & $100 \%$ & $100 \%$ & $100 \%$ & $100 \%$ & $100 \%$ & $100 \%$ & $100 \%$ & $100 \%$ & \\
\hline
\end{tabular}

Tablo 6. Tercih Nedeni-İletişime Geçme

Wattpad'den takip edip hoşlandığı yazarlar ya da yayıncılarla sosyal medya üzerinden geçenlerin \%51'i "Yazarı sevdiğimden" tercihinde bulunmuştur. "Yazarını sevdiğimden" $(\% 51,1)$ ardından, "Karakterleri kendime yakın bulduğum için" $(\% 50,7)$ belirgin tercih nedenleridir. 
Katılımcıları en çok etkileyen ve beğendikleri hikaye veya romanları belirlemek için sorulan soruya şıklar üzerinden verilen cevaplar incelendiğinde; katılımcıların \%29,1'inin en beğendiği hikaye "4N1K" olurken, en az beğenilen \%5,7 ile "Gözlük" hikayesi olmuştur.

\section{Wattpad'de okuduğunuz ve sizi en çok etkileyen (beğendiğiniz) hikayeler/romanlar} hangileridir?

\begin{tabular}{|c|c|c|c|}
\hline & & $\begin{array}{c}\text { Yanitlar } \\
\text { Sayı }\end{array}$ & Yüzde \\
\hline \multirow{7}{*}{$\begin{array}{l}\text { 11. Wattpad'de okuduğunuz ve sizi en } \\
\text { çok etkileyen (beğendiğiniz) } \\
\text { hikayeler/romanlar hangileridir? }\end{array}$} & $4 \mathrm{~N} 1 \mathrm{~K}$ & 163 & $29,1 \%$ \\
\hline & Ölüme F1sıldayan Adam & 109 & $19,4 \%$ \\
\hline & Kötü Çocuk & 103 & $18,4 \%$ \\
\hline & Sen on yedi yaşımsın & 62 & $11,1 \%$ \\
\hline & Yabanc1 & 58 & $10,3 \%$ \\
\hline & Psikopat & 34 & $6,1 \%$ \\
\hline & Gözlük & 32 & $5,7 \%$ \\
\hline \multirow{2}{*}{\multicolumn{2}{|c|}{ Toplam }} & & \\
\hline & & 561 & $100,0 \%$ \\
\hline
\end{tabular}

Tablo 7. En Çok Beğenilen Hikayeler/Romanlar

Ankete katılan Wattpad okuyucularının en beğendikleri yazarları belirlemek için sorulan soruya verilen cevaplar incelendiğinde; katılımcıların \%29'unun en çok beğendiği Wattpad yazarı "Büşra YILMAZ”, ikincisi ise \%19 oranla Miraç Çağrı AKTAŞ olmuştur.

En çok beğendiğiniz Wattpad yazarları kimlerdir?

\begin{tabular}{lllll} 
& & \multicolumn{2}{c}{ Yanıtlar } \\
& & Sayı & Yüzde \\
\hline & Büşra Yılmaz & 156 & $29,0 \%$ \\
\cline { 2 - 4 } & Miraç Çă̆ı Aktaş & 102 & $19,0 \%$ \\
\cline { 2 - 4 } Büşra Küçük & 92 & $17,1 \%$ \\
\cline { 2 - 4 } $\begin{array}{l}\text { 12 .En çok beğendiğiniz } \\
\text { Wattpad yazarları } \\
\text { kimlerdir? }\end{array}$ & Koray Yersüren & 47 & $8,7 \%$ \\
\cline { 2 - 4 } & Öznur Yıldırım & 42 & $7,8 \%$ \\
\cline { 2 - 4 } & Diğer & 31 & $5,8 \%$ \\
\hline Beyza Alkoç & 30 & $5,6 \%$ \\
\hline Zeynep Sey & 21 & $3,9 \%$ \\
\hline Mihri Mavi & 17 & $3,2 \%$ \\
\hline
\end{tabular}

Tablo 8.En Çok Beğenilen Wattpad Yazarı 
Wattpad okuyucularının tüm sorulara verdikleri cevapların eğitim seviyelerine göre anlamlı bir farklılık gösterip göstermediği Kruskal Wallis Testi ile incelenmiştir. Tablo 9'da farklılık gösterenler gösterilmiştir.

\begin{tabular}{|c|c|c|c|c|c|}
\hline & \begin{tabular}{|c|} 
Sizce \\
Wattpad'de \\
işlenen konular \\
hangi sıklıkta \\
şiddet içeriyor?
\end{tabular} & $\begin{array}{c}\text { Sizce } \\
\text { Wattpad'de } \\
\text { işlenen konular } \\
\text { hangi sıklıkta } \\
\text { cinsellik } \\
\text { içeriyor? }\end{array}$ & $\begin{array}{c}\text { Takip ettiğiniz } \\
\text { bir dergi var mı? }\end{array}$ & $\begin{array}{c}\text { Wattpad'den } \\
\text { takip edip } \\
\text { hoşlandığınız } \\
\text { yazarlar ya da } \\
\text { yayıncılarla } \\
\text { sosyal medyadan } \\
\text { iletişime geçiyor } \\
\text { musunuz? }\end{array}$ & $\begin{array}{c}\text { Wattpad'de } \\
\text { okuduğunuz bir } \\
\text { hikayenin TV } \\
\text { uyarlamasını da } \\
\text { izlemek ister } \\
\text { miydiniz? }\end{array}$ \\
\hline $\begin{array}{r}\text { Chi-square } \\
\text { Df } \\
\text { Asymp. Sig. }\end{array}$ & $\begin{array}{c}19,985 \\
2 \\
\mathbf{0 0 0}\end{array}$ & $\begin{array}{c}9,921 \\
2 \\
, 007\end{array}$ & $\begin{array}{c}8,835 \\
2 \\
, 012\end{array}$ & $\begin{array}{c}12,359 \\
2 \\
\mathbf{0 0 2}\end{array}$ & $\begin{array}{c}9,545 \\
2 \\
, 008\end{array}$ \\
\hline
\end{tabular}

a. Kruskal Wallis Test

b. Grouping Variable: Eğitim Seviyeniz

Tablo 9. Eğitim Seviyelerine Göre Farklılık Gösteren Cevaplar

Verilen cevaplarda eğitim seviyelerine göre anlamlı bir farklılık olup olmadığı test edildiğinde, yukarıda tabloda verilen 5 soruda eğitim seviyelerine göre istatistiksel olarak anlamlı bir farklılık gözlemlenmiştir. Bu soruların anlamlılık değerleri $\mathrm{p}=0,05$ 'ten küçüktür ve her bir madde için detaylı inceleme aşağıda yapılmıştır.

\begin{tabular}{|c|c|c|c|c|c|c|c|c|}
\hline & & & \multicolumn{5}{|c|}{$\begin{array}{l}\text { Sizce Wattpad'de işlenen konular hangi sıklıkta şiddet } \\
\text { içeriyor? }\end{array}$} & \multirow[b]{2}{*}{ Toplam } \\
\hline & & & Hiçbiri & Çok azı & Bazıları & Çoğunlukla & Hepsi & \\
\hline \multirow{3}{*}{$\begin{array}{l}\text { Eğitim } \\
\text { Seviyeniz }\end{array}$} & Ortaokul & $\begin{array}{l}\text { Say1 } \\
\%\end{array}$ & $\begin{array}{c}9 \\
7,7 \% \\
\end{array}$ & $\begin{array}{c}19 \\
16,2 \% \\
\end{array}$ & $\begin{array}{c}39 \\
33,3 \% \\
\end{array}$ & $\begin{array}{c}42 \\
35,9 \% \\
\end{array}$ & $\begin{array}{c}8 \\
6,8 \% \\
\end{array}$ & $\begin{array}{c}117 \\
100,0 \% \\
\end{array}$ \\
\hline & Lise & $\begin{array}{l}\text { Say1 } \\
\%\end{array}$ & $\begin{array}{c}2 \\
1,3 \% \\
\end{array}$ & $\begin{array}{c}19 \\
11,9 \% \\
\end{array}$ & $\begin{array}{c}47 \\
29,6 \% \\
\end{array}$ & $\begin{array}{c}83 \\
52,2 \% \\
\end{array}$ & $\begin{array}{c}8 \\
5,0 \% \\
\end{array}$ & $\begin{array}{c}159 \\
100,0 \% \\
\end{array}$ \\
\hline & Lisans & $\begin{array}{l}\text { Say1 } \\
\%\end{array}$ & $\begin{array}{c}0 \\
, 0 \% \\
\end{array}$ & $\begin{array}{c}2 \\
3,6 \% \\
\end{array}$ & $\begin{array}{c}12 \\
21,4 \% \\
\end{array}$ & $\begin{array}{c}34 \\
60,7 \% \\
\end{array}$ & $\begin{array}{c}8 \\
14,3 \% \\
\end{array}$ & $\begin{array}{c}56 \\
100,0 \% \\
\end{array}$ \\
\hline Toplam & & $\begin{array}{l}\text { Say1 } \\
\%\end{array}$ & $\begin{array}{c}11 \\
3,3 \%\end{array}$ & $\begin{array}{c}40 \\
12,0 \%\end{array}$ & $\begin{array}{c}98 \\
29,5 \%\end{array}$ & $\begin{array}{c}159 \\
47,9 \%\end{array}$ & $\begin{array}{c}24 \\
7,2 \%\end{array}$ & $\begin{array}{c}332 \\
100,0 \%\end{array}$ \\
\hline
\end{tabular}

Tablo 10. Eğitim Seviyesi*Şiddet İçeriği Sıklığı

Araştırmada “Sizce Wattpad'de işlenen konular hangi sıklıkta şiddet içeriyor?” sorusuna verilen cevaplarda öğrenim seviyelerine göre anlamlı farklılık saptanmıştır $(\mathrm{p}=0<0,05)$. Verilen cevaplar 
aşağıdaki tablodan incelendiğinde lisans öğrencilerinin büyük çoğunluğu (\%75'i), ortaokul öğrencilerinin \%41'i ve lise öğrencilerinin ise \%57'si Wattpad'de işlenen konuların şiddet içerdiğini düşünmektedirler. Buna göre, eğitim seviyesi yükseldikçe, Wattpad kitaplarında sıklıkla şiddetin yer aldığg düşüncesi de artmaktadır.

\begin{tabular}{|c|c|c|c|c|c|c|c|c|}
\hline & & & \multicolumn{5}{|c|}{$\begin{array}{l}\text { Sizce Wattpad'de işlenen konular hangi sıklıkta cinsellik } \\
\text { içeriyor? }\end{array}$} & \multirow[b]{2}{*}{ Toplam } \\
\hline & & & Hiçbiri & Çok azı & Bazıları & Çoğunlukla & Hepsi & \\
\hline \multirow{3}{*}{$\begin{array}{c}\text { Eğitim } \\
\text { Seviyeniz }\end{array}$} & Ortaokul & $\begin{array}{l}\text { Say1 } \\
\% \\
\end{array}$ & $\begin{array}{c}2 \\
1,9 \% \\
\end{array}$ & $\begin{array}{c}16 \\
15,4 \% \\
\end{array}$ & $\begin{array}{c}38 \\
36,5 \% \\
\end{array}$ & $\begin{array}{c}44 \\
42,3 \% \\
\end{array}$ & $\begin{array}{c}4 \\
3,8 \% \\
\end{array}$ & $\begin{array}{c}104 \\
100,0 \%\end{array}$ \\
\hline & Lise & $\begin{array}{l}\text { Say1 } \\
\%\end{array}$ & $\begin{array}{c}4 \\
3,0 \%\end{array}$ & $\begin{array}{c}13 \\
9,7 \%\end{array}$ & $\begin{array}{c}41 \\
30,6 \%\end{array}$ & $\begin{array}{c}68 \\
50,7 \%\end{array}$ & $\begin{array}{c}8 \\
6,0 \% \\
\end{array}$ & $\begin{array}{c}134 \\
100,0 \%\end{array}$ \\
\hline & Lisans & $\begin{array}{l}\text { Say1 } \\
\%\end{array}$ & $\begin{array}{c}1 \\
1,9 \%\end{array}$ & $\begin{array}{c}2 \\
3,8 \% \\
\end{array}$ & $\begin{array}{c}13 \\
24,5 \%\end{array}$ & $\begin{array}{c}31 \\
58,5 \%\end{array}$ & $\begin{array}{c}6 \\
11,3 \% \\
\end{array}$ & $\begin{array}{c}53 \\
100,0 \%\end{array}$ \\
\hline Toplam & & $\begin{array}{l}\text { Say1 } \\
\%\end{array}$ & $\begin{array}{c}7 \\
2,4 \%\end{array}$ & $\begin{array}{c}31 \\
10,7 \%\end{array}$ & $\begin{array}{c}92 \\
31,6 \%\end{array}$ & $\begin{array}{c}143 \\
49,1 \%\end{array}$ & $\begin{array}{c}18 \\
6,2 \%\end{array}$ & $\begin{array}{c}291 \\
100,0 \%\end{array}$ \\
\hline
\end{tabular}

Tablo 11. Eğitim Seviyesi* Cinsellik İçeriği Sıklığı

Araştırmada "Sizce Wattpad'de işlenen konular hangi sıklıkta cinsellik içeriyor?" sorusuna verilen cevaplarda öğrenim seviyelerine göre anlamlı farklılık saptanmıştır $(\mathrm{p}=0,007<0,05)$. Yukarıdaki çapraz tablo incelendiğinde ise ortaokul öğrencilerinin \%46's1, lise öğrencilerinin \%57's1 ve lisans öğrencilerinin ise \%70'i ise işlenen konuların cinsellik içerdiğini düşünmektedir. Yukarıdaki Tablo 10 'da belirtilenin bir benzeri olarak, eğitim seviyeleri yükseldikçe Wattpad hikayelerinde sıklıkla cinselliğin yer aldığı düşüncesi de artmaktadır.

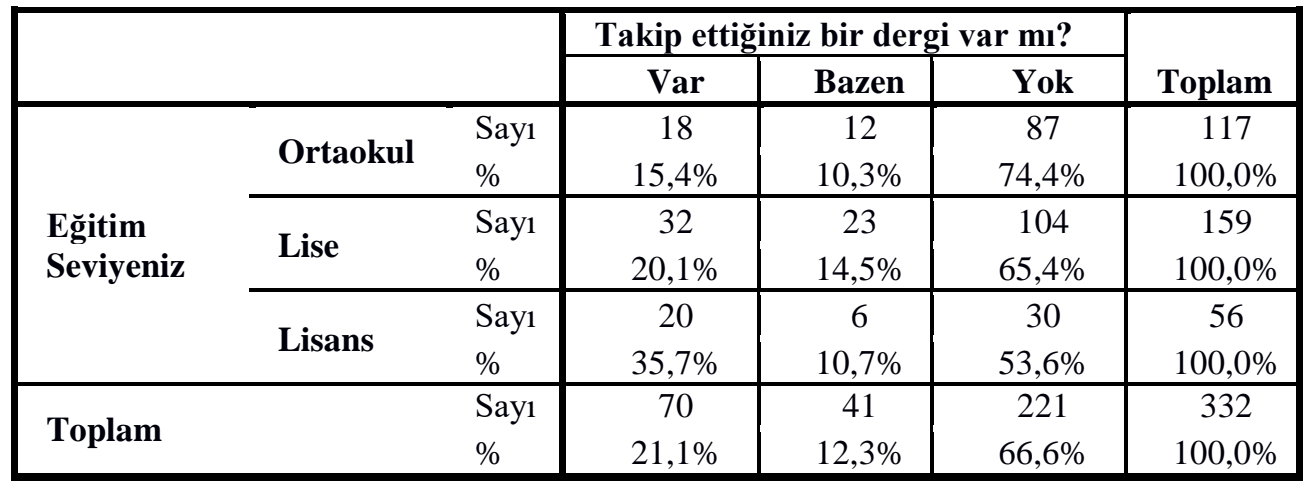

Tablo 12. Eğitim Seviyesi*Dergi Takibi

Katılımcıların düzenli olarak bir dergi takip edip etmedikleri sorulduğunda \%66,6'sı düzenli olarak herhangi bir dergi takip etmediklerini, \%21,1'i düzenli olarak takip ettiklerini, \%12,3'ü ise bazen cevabı vermişlerdir. Yapılan analizde dergi takibinin eğitim seviyelerine göre istatiksel olarak anlamlı bir farklılık $(\mathrm{p}=0,012<0,05)$ gösterdiği tespit edilmiştir. Lisans öğrencilerinin $\% 35,7$ 'si, lise öğrencilerinin \%20,1'i ve ortaokul öğrencilerinin ise \%15,4'ü bir dergi takip etmektedir. Eğitim seviyesi yükseldikçe dergi takip etme oranının arttığı gözlenmektedir.

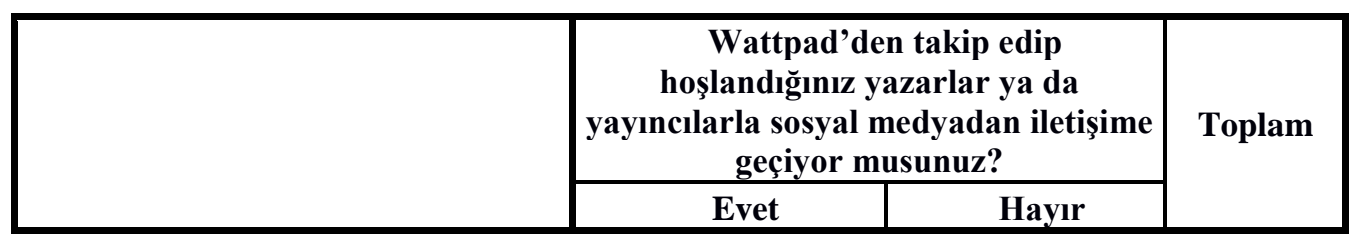




\begin{tabular}{|lcl|c|c|c|}
\hline & \multirow{2}{*}{ Ortaokul } & Say1 & 41 & 76 & 117 \\
& $\%$ & $35,0 \%$ & $65,0 \%$ & $100,0 \%$ \\
\cline { 2 - 6 } Eugitim & \multirow{2}{*}{ Lise } & Say1 & 70 & 89 & 159 \\
& $\%$ & $44,0 \%$ & $56,0 \%$ & $100,0 \%$ \\
\cline { 2 - 6 } & \multirow{2}{*}{ Lisans } & Say1 & 10 & 46 & 56 \\
& & $\%$ & $17,9 \%$ & $82,1 \%$ & $100,0 \%$ \\
\hline \multirow{2}{*}{ Toplam } & & Say1 & 121 & 211 & 332 \\
& & $\%$ & $36,4 \%$ & $63,6 \%$ & $100,0 \%$ \\
\hline
\end{tabular}

Tablo 13. Eğitim Seviyesi*Yazarların Sosyal Medyadan Takibi

Katılımcıların "Wattpad'den takip edip hoşlandığınız yazarlar ya da yayıncılarla sosyal medyadan iletişime geçiyor musunuz?" sorusuna verilen cevapların eğitim düzeylerine göre farklılık gösterip göstermediği test edildiğinde, istatistiksel olarak anlamlı bir farklılık saptanmıştır $(p=0,002<0,05)$. Bu durum daha detaylı Tablo 13'ten incelendiğinde ortaokul öğrencilerinin \%35'i, lise öğrencilerinin \%44'ü ve lisans öğrencilerinin ise \%18'i sosyal medya üzerinden iletişime geçtiklerini söylemişlerdir. Öğrencilerin en çok lisede ardından ortaokul ve lisans düzeyinde hoşlandıkları yazarlar ya da yayıncılar ile iletişime geçtikleri dikkat çekmektedir.

Ankete katılan Wattpad kullanıcılarının "Wattpad'de okuduğunuz bir hikayenin TV uyarlamasını da izlemek ister miydiniz?" sorusuna $\% 52$ 'si evet, $\% 21$ 'i hayır ve $\% 27$ ise fark etmez cevabını vermiştir. Katılımcıların eğitim seviyelerine göre verdiği cevaplarda $p=0,008<0,05$ olduğundan dolayı, bu soruya verilen cevaplar ile eğitim seviyelerine göre anlamlı bir farklılık vardır.

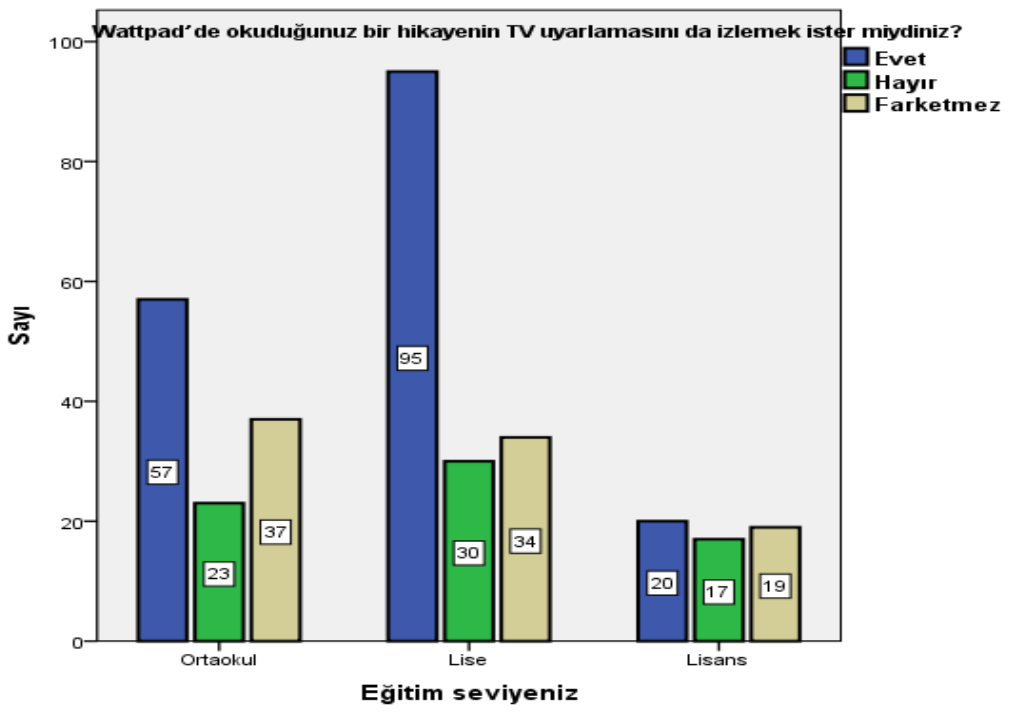

Tablo 14. Eğitim Seviyesi*TV Uyarlaması İzleme İsteği

Katılımcıların verdiği cevaplar arasında yapılan ilişki analizinde sadece 5 soruda istatistiksel olarak anlamlı bir ilişki çıkmıştır. Bu maddeler aşağıdaki Tablo 15'te verilmiş olup, daha sonra her bir ilişki için detaylı analiz yapılmıştır.

Korelasyonlar

\begin{tabular}{l|l|l|l|l|} 
S5 & S15 & S13 & S20 & S22 \\
\hline
\end{tabular}




\begin{tabular}{|c|c|c|c|c|c|c|c|c|}
\hline \multirow{5}{*}{$\begin{array}{l}\text { Spearman's } \\
\text { rho }\end{array}$} & & S3 & $\begin{array}{l}\text { Correlation Coefficient } \\
\text { Sig. (2-tailed) }\end{array}$ & $\begin{array}{l}, 412 \\
, 000\end{array}$ & & & & \\
\hline & ii. & S10 & $\begin{array}{l}\text { Correlation Coefficient } \\
\text { Sig. (2-tailed) }\end{array}$ & & $\begin{array}{l}, 316 \\
, 000 \\
\end{array}$ & & & \\
\hline & iii. & S16 & $\begin{array}{l}\text { Correlation Coefficient } \\
\text { Sig. (2-tailed) }\end{array}$ & & & $\begin{array}{l}, 313 \\
, 000 \\
\end{array}$ & & \\
\hline & iv. & S19 & $\begin{array}{l}\text { Correlation Coefficient } \\
\text { Sig. (2-tailed) }\end{array}$ & & & & $\begin{array}{l}, 324 \\
, 000\end{array}$ & \\
\hline & & $\mathbf{S 2 3}$ & $\begin{array}{l}\text { Correlation Coefficient } \\
\text { Sig. (2-tailed) }\end{array}$ & & & & & $\begin{array}{l}, 492 \\
, 000 \\
\end{array}$ \\
\hline
\end{tabular}

Tablo 15. Aralarında Anlamlı Korelasyon Gösteren Maddeler

Yapılan analize göre:

i. $\quad$ Eğitim Görülen Okul Türü*Ailenin Aylık Geliri:

Eğitim görülen okul türü ile ailenin aylık geliri arasında anlamlı bir ilişki $(\mathrm{p}=0,00<0,05)$

bulunmaktadır. Korelasyon katsayısı r=0,412 ile iki değişken arasında pozitif yönde düşük seviyede ilişki vardır. Ailenin gelir düzeyi arttıkça özel okul tercihi de artmaktadır. Ankete katılan ve aylık geliri 8.000 TL üzerinde olan öğrencilerin tamamı özel okulda öğrenim görmektedir. Öte yandan aylık geliri 4.000TL altında olan öğrencilerin \%83'ü devlet okuluna devam etmektedir.

ii. Wattpad'den takip edip hoşlandı̆̆ınız yazarlar ya da yayıncılarla sosyal medyadan iletişime geçiyor musunuz?* Wattpad'de okuduğunuz bir hikâyenin TV uyarlamasını da izlemek ister miydiniz?

Wattpad'den takip edilen yazar ve yayınların sosyal medyada iletişime geçme durumu ile okunan hikayenin TV uyarlamasını izleme isteği arasında istatistiksel olarak anlamlı bir ilişki $(p=0,00<0,05)$ vardır. Korelasyon katsayısı r=0,316 ile iki değişken arasında pozitif yönde düşük seviyede ilişki vardır. Sosyal medya üzerinden yazar ve yayıncılarla iletişime geçenlerin \%75'i, Wattpad'de okuduğu bir hikayenin TV uyarlamasını izlemek istemektedir. Diğer yandan TV uyarlamasını izlemek istemeyenlerin \%83'ü de sosyal medya üzerinden yazar ve yayınevleri ile iletişime geçmediklerini belirtmişlerdir.

iii. Haftada ne kadar Wattpad okursunuz?* Okuduğunuz Wattpad kitaplarını arkadaşlarınıza hangi sıklıkla öneriyorsunuz?

Ankete katılan öğrencilerin haftalık Wattpad okuma süreleriyle, okudukları kitapları arkadaşlarına önerme sıklıkları arasında istatistiksel olarak anlamlı bir ilişki ( $p=0,00<0,05)$ gözlemlenmiştir. Pozitif yönde olan bu ilişkinin katsayısı r=0,313'tür. Bu durum aşağıdaki Tablo 16'da yer alan değişkenlerin değerleri incelenecek olunursa;

Haftada 0-30 dk arası Watpadd okuyan katılımcıların \%44'ünün, 30dk-1saat arasında okuyanların da \%34,4'ünün arkadaşlarına pek tavsiyede bulunmadıkları öte yandan 5-10 saat arasında 
okuyanların \%70'inin, 10 saatten fazla okuyanların ise \%67'sinin arkadaşlarına tavsiyede bulunmakta oldukları gözlemlenmiştir.

\section{Haftada ne kadar Wattpad okursunuz? * Okuduğunuz Wattpad kitaplarını arkadaşlarınıza hangi sıklıkla öneriyorsunuz? Çapraz Tablolama}

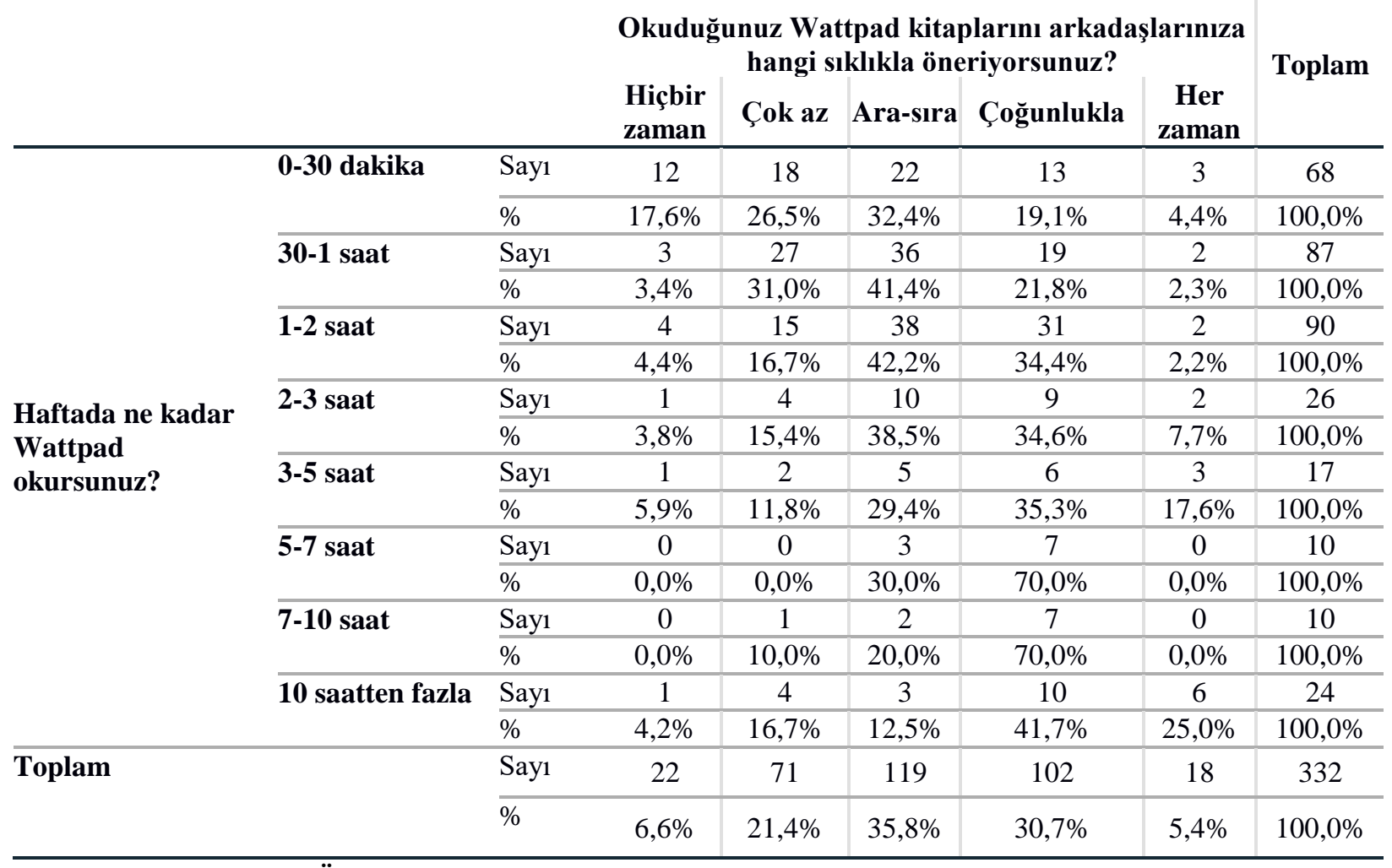

Tablo 16. Okuma Süresiº̈neri Sıklığı

iv. Siz de Wattpad'de hikaye yazdınız mı?* Siz de Wattpad'de hikaye yazmak ister misiniz?

Wattpad'de hikaye yazmak isteyip de henüz hikaye yazamamış olanların oranı \%77'dir. Hikaye yazma durumuyla, hikaye yazma isteği arasında istatistiksel olarak anlamlı bir ilişki $(\mathrm{p}=0,00<0,05)$ vardır. Korelasyon katsayısı r=0,324 ile iki değişken arasında pozitif yönlü düşük oranlı bir ilişki mevcuttur.

v. Sizce Wattpadde işlenen konular hangi sıklıkta cinsellik içeriyor?* Sizce Wattpadde işlenen konular hangi sıklıkta şiddet içeriyor?

Wattpadde konularının içerisinde cinsellik bulunması ile şiddet bulunması arasında anlamlı bir ilişki $(\mathrm{p}=0,00<0,05)$ bulunmaktadır. Korelasyon katsayısı $\mathrm{r}=0,492$ ile iki değişken arasında pozitif yönde düşük seviyede ilişki vardır. Wattpad konularının hepsinin cinsellik içerdiğini düşünenlerin \%83'ü ya çoğunluğunda ya da tamamında şiddet içerildiğini ifade etmişlerdir. Ayrıca çoğunlukla cinsellik içerdiğini düşünenlerin \%71'i çoğunlukla şiddet içerdiğini de düşünmektedir.(Tablo 17) 
Sizce Wattpad'de işlenen konular hangi sıklıkta cinsellik içeriyor? * Sizce Wattpad'de işlenen konular hangi sıklıkta şiddet içeriyor? Çapraz Tablolama

Sizce Wattpad'de işlenen konular hangi sıklıkta şiddet içeriyor?

\begin{tabular}{|c|c|c|c|c|c|c|c|c|}
\hline & & & Hiçbiri & Çok azı & Bazıları & Çoğunlukla & Hepsi & Toplam \\
\hline \multirow{10}{*}{$\begin{array}{l}\text { Sizce } \\
\text { Wattpad'de } \\
\text { işlenen } \\
\text { konular } \\
\text { hangi } \\
\text { sıklıkta } \\
\text { cinsellik } \\
\text { içeriyor? }\end{array}$} & Hiçbiri & Say1 & 0 & 1 & 3 & 2 & 1 & 7 \\
\hline & & Yüzde(\%) & $0,0 \%$ & $14,3 \%$ & $42,9 \%$ & $28,6 \%$ & $14,3 \%$ & $100,0 \%$ \\
\hline & Çok azı & Say1 & 2 & 11 & 13 & 3 & 2 & 31 \\
\hline & & Yüzde(\%) & $6,5 \%$ & $35,5 \%$ & $41,9 \%$ & $9,7 \%$ & $6,5 \%$ & $100,0 \%$ \\
\hline & Bazıları & Say1 & 2 & 13 & 42 & 35 & 0 & 92 \\
\hline & & Yüzde(\%) & $2,2 \%$ & $14,1 \%$ & $45,7 \%$ & $38,0 \%$ & $0,0 \%$ & $100,0 \%$ \\
\hline & Çoğunlukla & Say1 & 1 & 6 & 24 & 102 & 10 & 143 \\
\hline & & Yüzde(\%) & $0,7 \%$ & $4,2 \%$ & $16,8 \%$ & $71,3 \%$ & $7,0 \%$ & $100,0 \%$ \\
\hline & Hepsi & Say1 & 0 & 0 & 3 & 6 & 9 & 18 \\
\hline & & Yüzde(\%) & $0,0 \%$ & $0,0 \%$ & $16,7 \%$ & $33,3 \%$ & $50,0 \%$ & $100,0 \%$ \\
\hline \multirow[t]{2}{*}{ Toplam } & & Say1 & 5 & 31 & 85 & 148 & 22 & 291 \\
\hline & & Yüzde(\%) & $1,7 \%$ & $10,7 \%$ & $29,2 \%$ & $50,9 \%$ & $7,6 \%$ & $100,0 \%$ \\
\hline
\end{tabular}

Tablo 17. Cinsellik* Şiddet İlişkisi

Ankete katılan okuyucularının \%14'ü daha önce Wattpad'de hikaye yazmışken \%86'sı ise henüz hikaye yazmamıştır. Katılımcıların yarısı Wattpad'de hikaye yazmak istediklerini belirtmiştir. Hikaye yazmak ister misiniz sorusuna verilen cevaplar eğitim düzeylerine göre incelendiğinde ise hem ortaokul, hem lise hem de üniversite düzeyinde tüm katılımcıların yarısı evet derken, diğer yarısı hayır demiştir.

Ankete katılanların verdikleri cevapların haftalık Wattpad okuma sıklıklarına göre istatistiksel olarak anlamlı bir farklılık olup olmadığı Kruskal Wallis Testi ile incelenmiştir. Okuma sıklıklarına göre anlamlı farklılıkları olan maddeler aşağıdaki Tablo 18'de verilmiştir.

\begin{tabular}{|c|c|c|c|c|c|}
\hline \multicolumn{6}{|c|}{ Haftada Ne kadar Wattpad Okursunuz? } \\
\hline & $\begin{array}{l}\text { Wattpad'den } \\
\text { takip edip } \\
\text { hoşlandığınız } \\
\text { yazarlar ya da } \\
\text { yayıncılarla } \\
\text { sosyal } \\
\text { medyadan } \\
\text { iletişime } \\
\text { geçiyor } \\
\text { musunuz? }\end{array}$ & $\begin{array}{l}\text { Okuduğunuz } \\
\text { Wattpad } \\
\text { kitaplarını } \\
\text { arkadaşlarınıza } \\
\text { hangi sıklıkla } \\
\text { öneriyorsunuz? }\end{array}$ & $\begin{array}{l}\text { Wattpad'de } \\
\text { okuduğunuz bir } \\
\text { hikayenin TV } \\
\text { uyarlamasını da } \\
\text { izlemek ister } \\
\text { miydiniz? }\end{array}$ & $\begin{array}{l}\text { Siz de } \\
\text { Wattpad'de } \\
\text { hikaye } \\
\text { yazdınız mı? }\end{array}$ & $\begin{array}{l}\text { Siz de } \\
\text { Wattpad'de } \\
\text { hikaye yazmak } \\
\text { ister misiniz? }\end{array}$ \\
\hline $\begin{array}{l}\text { Chi- } \\
\text { square }\end{array}$ & 26,891 & 34,414 & 36,905 & 30,096 & 26,205 \\
\hline Df & 7 & 7 & 7 & 7 & 7 \\
\hline $\begin{array}{l}\text { Asymp. } \\
\text { Sig. }\end{array}$ &, 000 &, 000 & 000 & ,000 &, 000 \\
\hline
\end{tabular}


a. Kruskal Wallis Test
b. Grouping Variable: Haftalık Wattpad Okuma Sıklığı

Tablo 18. Wattpad Okuma Sıklıklarına Göre Anlamlı Farklılık Gösteren Maddeler

Anketi cevaplayanların okuma sıklıklarına göre yukarıdaki 5 maddenin anlamlılık değeri 0,05'ten küçüktür.

Hoşlandığı yazarlar ya da yayıncılarla sosyal medyadan iletișime geçmeyenler, toplamın \%64'ünü oluşturmasına karşın, haftada 5-7 saat arasında Wattpad okuyanların \%70'i, 3-5 saat okuyanların \%65'i hoşlandığ 1 yazarlar ya da yayıncılarla sosyal medyadan iletişime geçtikleri görülmüştür. Okuma oranı arttıkça yazarlarla iletişime geçme oranını da artması önemli bir bulgudur.

Haftada 5 saat ve üzerinde Wattpad okuyan öğrencilerin, arkadaşlarına Wattpad kitaplarını önerme sıklıklarının gözle görülür oranda arttıkları tespit edilmiştir.

Wattpad okuma sıklığıyla TV uyarlama isteği arasında ciddi bir ilişki gözlenmiştir. Buna göre Haftada 0-30dk arasında Wattpad okuyanların \%54'ü, 1-2 saat arasında okuyanların \%77'si ve 10 saatten fazla okuyanların \%91'i TV uyarlamasını istemektedir.

Ankete katılanların \%13,6'sı Wattpad hikayesi yazmışken, haftada 5-10 saat arası Wattpad okuyanlarda bu oran \%25'e, 10 saatten fazla okuyanlarda ise bu oran \%42'lere çıkmaktadır.Haftada 2-3 saat Wattpad okuyanların Wattpad hikayesi yazma isteği ise \%81'le en yüksek seviyededir.

\section{Değerlendirme}

Wattpad kullanıcı/okurlarının Wattpad okuma alışkanlıklarını ve Wattpad'i tercih nedenlerini belirlemeye çalıştığımız araştırmamız, bu konuya yönelik sınırlı sayıda çalışma bulunduğundan, özellikle kullanıcı/okur profilini anlamaya yönelik ilk çalışma olarak nitelendirilebilir. Bu bağlamda, çalışmada kullanıcı/okur açısından mevcut durum tesbiti yapılmış olup; gelecekte yapılacak çalışmalarla daha derinlemesine analizler için bir ölçek geliştirilebilmesi önerilmektedir.

Araştırmaya göre okur profilinin, genel yaş ortalaması 15,6 çıkarken, okur kitlesinin genel yaş ortalaması itibariyle, lise çağındaki öğrencilerden oluştuğu, ancak okur profilinin en alt yaş sınırının ise ortaokul öğrencilerine kadar ulaştığı görülmektedir. Okur profilinin eğitim aldıkları kurumların türü sorgulandığında ise \%80 oranında, araştırmaya katılan Wattpad kullanıcılarının devlet okullarında eğitim gördükleri ortaya çıkmıştır.

Araştırmaya katılan okurların yarıdan fazlasının yani \%60'ının Wattpad'den arkadaşları aracılığıyla haberdar olduklarını belirtmek gerekir. Geri kalanların yarısı sosyal medya aracılığıya, diğer yarısı ise internet siteleri sayesinde Wattpad'den haberdar olmuşlardır. Bu sonuçtan da anlaşıldığı gibi sosyal çevre yani arkadaş grubu ve sosyal mecralar Wattpad okumaya başlamakta, Wattpad'i tercih etmekte çok önemli bir etkendir. Bu durum, çalışmamızın başında söz ettiğimiz hipotezlerinden ilki 
olan, Wattpad okuma tercihinde arkadaş ve sosyal çevrenin etkisinin bulunduğu tezini doğrulamaktadır.

Bir başka deyişle, Wattpad'in yaygınlık kazanmasında arkadaşların, sosyal grupların etkisi diğer mecralara kıyasla çok daha fazladır. Bu sonuç, genç yaştaki okur kitlesinin yine en çok kendi yaş grubundan etkilenerek okuma tercihlerini, okuma alışkanlıklarını şekillendirdiğini göstermektedir.

Çalışmamızda bir transmedya örneği olarak temellendirdiğimiz Wattpad'i diğer kitaplardan ve okuma türlerinden ayıran en belirgin nokta, okurlarının Wattpad yazarlarına ulaşma ve onlarla iletişim kurabilme imkanı ile içeriklere katkı sağlayabilme imkanlarının bulunmasıdır. Bu nedenle okurlara herhangi bir Wattpad yazar ya da karakterinin fun club yani hayran gruplarına üyeliği olup olmadığı sorulmuştur. Öte yandan aynı şekilde Wattpad yazar ya da yayıncılarıyla sosyal medyadan iletişime geçip geçmedikleri sorusu yöneltilmiştir. Araştırmaya katılan 117 kişi (\%36) fun cub üyeliklerinin olduğunu belirtirken, 197kişi (\%64) henüz bir fun cluba üye olmadıklarını ifde etmişlerdir. Çapraz tablolamada bu her iki sorunun incelenmesiyle ilginç bir sonuca ulaşılmıştır. Herhangi bir fun club üyeliği olmasa da beğendiği yazar ya da yayıncılarla sosyal medyadan iletişime geçenlerin oranı oldukça yüksek bir oran $\% 28,8$ 'dir. Öte yandan fun club üyeliği olanların \% 77,8'i de aynı zamanda beğendikleri yazar ya da yayıncılarla sosyal medya üzerinden iletişim kurmaktadır. Bu sonuç da Wattpad'in transmedya özelliğini yani okurların yazar ve yayıncılara ulaşarak, Wattpad içeriğine yorumlarıyla katkı sağlamak istediklerini göstermektedir. Çalışmamızın Wattpad yazarları ile kurulan iletişimin okuma alışkanlıklarını olumlu yönde etkilediği hipotezinin de doğrulandığı görülmektedir.

Wattpad okumaya ayrılan süreyi açığa çıkarmak amacıyla, araştırmaya katılanlara haftada kaç saat Wattpad okudukları sorusu yöneltilmiştir. Ulaşılan sonuca göre, okurların \% 74 'ü haftada 2 saat ve daha az Wattpad okumaktadır. Öte yandan, \%7'nin üzerinde bir oranda haftada 10 saatten fazla Wattpad okunmaktadır. Bu da Wattpad okumaya ayrılan zaman açısından önemli ve yüksek bir oran olarak görülmektedir.

Wattpad kullanıcılarının bir transmedya örneği olarak, başka mecralarda da Wattpad içeriklerini takip etme isteklerini ölçmek amaçlı olarak sorulan, "Wattpad'de okuduğunuz bir hikayenin TV uyarlamasını da izlemek ister miydiniz?" sorusuna \%52'si evet, $\% 21$ 'i hayır ve $\% 27$ ise fark etmez cevabını vermiştir. Katılımcıların bu soruya verdikleri cevaplar ile eğitim seviyelerine göre anlamlı bir farklılık bulunmakta; lise ile ortaokul öğrencilerinin çok büyük bir oranla soruya olumlu cevap verdikleri görülmektedir. Aynı zamanda haftalık Wattpad okuma süresi arttıkça tv uyarlaması talebi de artmaktadır. Bu sonuç, izlerkitlenin transmedya hikayeciliğinde, farklı mecralarda hikayenin değişik boyutlarını takip etme ve onlara katkı sağlama talebinde bulunduğunun bir göstergesidir. $\mathrm{Bu}$ bağlamda, çalışmada Wattpad okurlarının beğendikleri içerikleri, transmedya biçiminde farklı mecralarda da takip etmeyi tercih ettikleri yönündeki sonuncu hipotezimiz de doğrulanmıştır. Çalışmanın sonucunda tüm hipotezlerin doğrulandığı görülmektedir.

\section{Sonuç}

Çalışmanın başında ortaya konan hipotezlerin doğrulanmasıyla çıkan sonuçlara göre, \%92'lik bir oranla akıllı telefonlardan takip edilen Wattpad'i okuma tercihinde arkadaş ve sosyal çevrenin birincil derecede etkisi bulunmakta, Wattpad yazarları ile kurulan iletişimin Wattpad okuma süresini arttırmakta ve okuma alışkanlıklarını olumlu yönde etkilemektedir. 
Çalışmada, Wattpad okur/kullanıcı profilinin Wattpad içeriklerine katkı sağlama ve hikayeleri aktif bir şekilde yönlendirme talebinde olduğu; farklı mecralarda aynı içeriğin çeşitli şekillerde sunumunu, diğer bir deyişle transmedya anlatımını takip ettikleri görülmektedir. Bu durum ankette yer alan yazar ve yayıncıyla iletişime geçer misiniz ve okuduğunuz Wattpad hikayesinin TV uyarlamasını da izlemek ister misiniz sorularına yüksek oranlarda verilen olumlu yanıtlardan anlaşılmaktadır.

Wattpad kullanıc1/okurlarının, araştırmamıza göre ortalaması 15,6 olan oldukça genç bir hayran kitleden oluştuğu dikkate alındığında söz konusu kitlenin, Storey’in (2000) alt kültür gençliği için sözünü ettiği gibi kendilerini egemen kültür ve ebeveyn karşıtı; hayran topluluklarının ise gündelik hayatın sıradanlığının ve kültürel pasifliğinin karşıtı şeklinde konumlandırdıklarını görmek mümkündür. Çalışmada Wattpad hikayelerinin büyük oranda cinsellik ve şiddet barındırdığı yönünde verilen cevaplar da yine daha önce sözü edilen Karauğuz'un (2016) çalışmasındaki gibi Wattpad içeriklerinde genellikle gündelik hayatın rutini dışında, uçlarda yaşayan karakterler ve ütopik konular bulunduğunu desteklemektedir. Araştırmada okuma tercih nedenleri arasında ilk sırada yer alan mizahi dili ve hemen ardından gelen seçenek olarak heyecanlı ve romantik anlatımıyla tanımlanan Wattpad hikayelerinin, büyük çoğunluğu genç kızlardan oluşan okur ve hayran kitlesinin kendi günlük hayatının, rutinin dışına çıkarak kendi yaşayamadığı pek çok tecrübeyi okuduğu bir alan olarak da tanımlanabilir.

Bir transmedya hikaye anlatısı olarak, Wattpad'in yaygınlık kazanmasında, tercihinde arkadaşların, sosyal grupların etkisi diğer mecralara kıyasla çok daha fazladır. Bu sonuç, genç yaştaki okur ve hayran kitlesinin yine en çok kendi akran grubundan etkilenerek okuma tercihlerini, okuma alışkanlıklarını şekillendirdiğini göstermektedir. Okuma alışkanlığı kazandıktan sonra, Wattpad okumaya ayrılan sürenin ise, okurun kendi arkadaşlarına Wattpad'i tavsiye etmesini, kendisinin de bir Wattpad hikayesi yazmasını, ayrıca transmedya anlatı olarak başka mecralarda da aynı içeriği takip etme talebini arttırmaktadır. 


\section{Kaynakça}

Aytan, T. (2017). Evaluation of Electronic Writing Experiences of Turkish Teacher Candidates at WATTPAD Environment, Higher Education Studies; Vol. 7, No. 4; Published by Canadian Center of Science and Education

Bold, M. R. (2016). The return of the social author: Negotiating authority and influence on Wattpad, Convergence: The International Journal of Research into

Çoban, O. (2015). Yoksa Sen Daha Okumadın Mı?: Bir Online Okuma Platformu Olarak Wattpad Ve Sanal Dünyanın Gençlerinde Sanal Okuma Kültürü, Şimşek, T. Yıldız, B. V. (Yayına Hz.), 2. Uluslararası Çocuk ve Gençlik Edebiyatı Sempozyumu Bildiriler içinde, (s.593-598), İstanbul: KBN Dijital Bask1 Tesisleri. Jenkins, H. (2016). Cesur Yeni Medya, Teknolojiler ve Hayran Kültürü, İstanbul: İletişim Yayınları.

Karauğuz, A.M. (2016). Dijital Tablete Yazı Yazmak ya da Wattpad Romanları, Hece Aylık Edebiyat Dergisi, Y11: 20, Say1: 234-235-236, Ankara.

Laughey, D. (2010) Medya Çalışmaları Teoriler ve Yaklaşımlar, İstanbul: Kalkedon Yayınları.

Sarı, G. (2017). Transmedya hikâye anlatıcılığı: Kötü Çocuk örneğı Abant Kültürel Arastırmalar Dergisi (AKAR), Cilt 2, Say1 4, 245-253.

Sezen, D. (2014). Transmedya Hikayeciliği, Karaçor, S. Aydın, D. \& Gülerarslan, A. (Edt.). Transmedya Hikayeciliği içinde, (s. 39-56), Konya: Çizgi Kitabevi.

Storey, J. (2000). Popüler Kültür Çalışmaları Kuramlar ve Metotlar, İstanbul: Babil Yayınları. 